\title{
ПОЛУЧЕНИЕ ПОЛИСТИРОЛЬНЫХ МИКРОСФЕР, ЗАПОЛНЕННЫХ РОДАМИНОМ G
}

\author{
П.А. Чичева, В.Р. Курбангалеев, К. С. Левченко, П. С. Шмелин, Е. П. Гребенников \\ ПОЛИНА АНДРЕЕВНА ЧИЧЕВА - инженер-технолог 1 категории АО «ЦНИТИ «Техномаш». \\ E-mail: pchicheva@mail.ru. \\ ВАГИЗ РАВИЛЕВИЧ КУРБАНГАЛЕЕВ - начальник лаборатории АО «ЦНИТИ «Техномаш». \\ E-mail: kurbangaleev@cnititm.ru.
}

КОНСТАНТИН СЕРГЕЕВИЧ ЛЕВЧЕНКО - к.х.н., начальник лаборатории АО «ЦНИТИ «Техномаш».

E-mail: k.s.levchenko@gmail.com.

ПАВЕЛ СЕРГЕЕВИЧ ШМЕЛИН - начальник отдела АО «ЦНИТИ «Техномаш».E-mail: shmelin@cnititm.ru.

ЕВГЕНИЙ ПЕТРОВИЧ ГРЕБЕННИКОВ - д.т.н., директор по науке АО «ЦНИТИ «Техномаш».

E-mail: grebennikov@cnititm.ru.

121108, г. Москва, ул. Ивана Франко, 4, Акциионерное общество «Центральный научно-исследовательский технологический институт «Техномаш».

Полимерные микросферы находят широкое применение в научных исследованиях, медицине, биомедииинских анализах, фармачевтических препаратах, нанотехнологиях и электронике, благодаря возможности формирования на их поверхности функиионального молекулярного слоя, который может содержать, например, антитела, антигены, пептиды или нуклеиновые кислоты, а также гидрофобные красители и другие соединения. Простые полистирольные микросферы широко используются в различных диагностических тестах и анализах. В данной работе были синтезированы полистирольные наносферы, заполненные флуоресиентным красителем родамином G. Полученные флуоресиентные микросферы были характеризуются средним размером около 50 нм по данным методов лазерной дифракиии и атомно-силовой микроскопии и узким распределением частии по размерам. Максимум флуоресиенции наносфер при 555 нм соответствует флуоресиенции родамина $G$.

Ключевые слова: полистирол, наносферы, родамин G, атомно-силовая микроскопия, флуоресценция.

\section{PREPARATION OF POLYSTYRENE MICROSPHERES FILLED WITH RHODAMINE G}

\author{
P.A. Chicheva, V.R. Kurbangaleev, K.S. Levchenko, P. S. Shmelin, E. P. Grebennikov \\ 4, Ivana Franko Str., Moscow, 121108, Russia, JSC «Technomash».
}

Polymeric microspheres are widely used in scientific research, medicine, biomedical analyzes, pharmaceuticals, nanotechnology and electronics due to the possibility of forming on their surface a functional molecular layer, which may contain, for example, antibodies, antigens, peptides or nucleic acids, as well as hydrophobic dyes 
and other compounds. Simple polystyrene microspheres are widely used in various diagnostic tests and analyzes. In this work, polystyrene nanospheres filled with a fluorescent dye rhodamine $G$ were synthesized. The obtained fluorescent microspheres were characterized by an average size of about $50 \mathrm{~nm}$ according to the methods of laser diffraction and atomic force microscopy and a narrow particle size distribution. The maximum fuorescence of nanospheres at $555 \mathrm{~nm}$ corresponds to the fluorescence of rhodamine $G$.

Keywords: polystyrene nanospheres, rhodamine g, atomic force microscopy, fluorescence.

\section{Введение}

Полимерные микро и наносферы находят широкое применение в научных исследованиях, медицине, биомедицинских анализах, фармацевтических препаратах, нанотехнологиях и электронике, благодаря возможности формирования на их поверхности функционального молекулярного слоя. Простые полистирольные микросферы широко используются в различных диагностических тестах и анализах. Монодисперсные полимерные микросферы также находят широкое применение в качестве стандартов для калибровки и настройки приборов.

Микросферы, наполненные флуоресцентными молекулами или частицами, имеют широкое поле применений, включая визуализацию и диагностику, а также могут использоваться для исследований механики жидкости, новых лекарств, флуоресцентной микроскопии, фагоцитоза и др.

Бывают твердые и полые частицы, которые сильно различаются по плотности и, как следствие, различается их применение. Полые сферы обычно используются в качестве добавок для снижения плотности материала. Твердые частицы имеют множество применений в зависимости от того, из какого материала они изготовлены и какой размер имеют.

Например, в медицине микросферы применяют для локальной доставки лекарственных средств к органам и тканям. В этом случае они выступают в качестве матричных систем, в которых диспергировано лекарственное вещество. Для этих целей используют как биоразлагаемые, так и синтетические полимерные сферы [1].

Модифицированные сферы из полистирола и полиэтилена широко применяют в диагностике. Они могут быть покрыты распознающими молекулами, такими как антитела, антигены, пептиды и т.д.

Частицы полимерного латекса используются в тестовых системах в качестве иммуноадсорбентов. Для химического связывания полимерных частиц с иммунопротеинами они должны быть модифицированы по поверхности функциональными группами. Связь между поверхностью и белками должна быть достаточно прочной, чтобы предотвратить неспецифические реакции. Принцип работы иммунохимических тестов основан на комплементарности антигенов (Ag) и антител (Ab). При присоединении $\mathrm{Ab}$ к поверхности полимерной частицы, содержащей $\mathrm{Ag}$, происходит изменение оптических свойств раствора, содержащего модифицированные сферы, как показано на рисунке 1 , в частности к помутнению.

Полистирольные наносферы окрашенные флуоресцентным красителем, таким как родамин $\mathrm{G}$, представляют интерес для создания иммунологического теста, работа которого основана на изменении интенсивности флуоресценции.

В данной работе были синтезированы полистирольные наносферы размером 50 нм, наполненные флуоресцентным красителем родамин G.

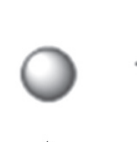

A

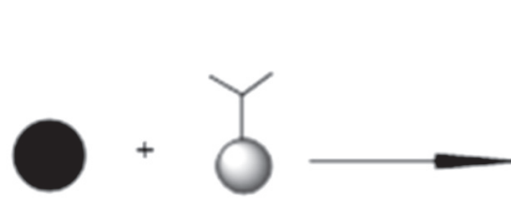

Ag

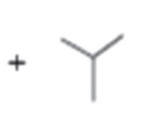

b

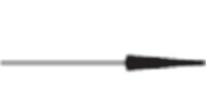

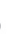

C

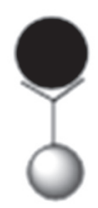

$\mathbf{A b} * \mathbf{A g}$
Рис. 1. Синтез конъюгата и взаимодействие антитела с антигеном (Ag) при иммунохимическом анализе

$\mathbf{A}$-микросфера; $\mathbf{b}$ - антитело; $\mathbf{C}$ - иммуномикросфера

\section{Материалы}

В работе использовались стирол и дивинилбензол (Sigma-Aldrich, США), предварительно очищенные от ингибитора вакуумной дистилляцией на вакуумном роторном испарителе; лаурилсульфат натрия (ЛСН) и персульфат калия (ПК) 
(РусХим, Россия); родамин G (Реахим, Россия); вода дистиллированная.

\section{Синтез флуоресцентных полистирольных наносфер}

Наносферы получали методом эмульсионной полимеризации стирола. Реакцию проводили в трехгорлой колбе, снабженной обратным холодильником, термометром и магнитной мешалкой. В колбу налили дистиллированную воду, в которой при перемешивании растворили эмульгатор ЛСН, инициатор - ПК и флуоресцентный краситель - родамин G. Смесь мономеров стирола и дивинилбензола приготовили отдельно, после чего в один прием при быстром перемешивании добавили к водной фазе.

Реакционную смесь постепенно нагревали до температуры полимеризации $80{ }^{\circ} \mathrm{C}$, предварительно продув колбу аргоном. Через $10-15$ минут после начала полимеризации смесь начинала опалесцировать вследствие образования полимерных частиц. Полимеризацию проводили в течении 5 часов. Рецептура полимеризации представлена в таблице 1 .

Таблииа 1

Рецептура полимеризации

\begin{tabular}{cc}
\hline Наименование & Навеска \\
\hline Стирол & 10 г \\
Дивинилбензол & 0,7 г \\
ЛСН & 0,125 г \\
ПК & 0,125 г \\
Вода & 110 мл \\
Родамин G & 50 мг \\
\hline
\end{tabular}

По окончании синтеза частицы выделили из полимеризационной смеси, упарив воду под вакуумом на роторном испарителе. Полимер тщательно промыли этанолом и водой с целью удаления красителя, оставшегося на поверхности частиц.

\section{Изучение размера частиц}

Оценку геометрических размеров осуществляли с помощью метода лазерной дифракции. Размеры полученных полистирольных сфер были определены с помощью лазерного анализатора размера частиц Zetatrack (Zetatrac Inc, США). Измерение проводились со следующими параметрами сканирования: длительность анализа 1 минута, растворитель - вода. Установлено, что синтезиро- ванные частицы отличаются узким распределением по размерам, а средний размер частиц составляет 50 нм.

Таким образом, результаты определения размеров частиц позволяют утверждать, что данная методика синтеза полистирольных наносфер позволяют получать частицы заданного размера с узким распределением частиц.

\section{Исследование частиц с помощью атомно- силовой микроскопии Флуоресценция}

Полученные частицы были исследованы с помощью атомно-силового микроскопа Agilent AFM 5420. Для этого на поверхности предварительно отмытых стеклянных подложек методом полива формировали пленки из раствора полученных частиц. Поверхность формируемых пленок измерялась бесконтактным методом в осцилляционном режиме сканирования зонда.

В измерениях использовался зонд NSG01_DLC (НТ-МДТ, Россия) со следующими номинальными характеристиками:

- длина кантилевера: 130 мкм;

- ширина кантилевера: 35 мкм;

- толщина кантилевера: $1,7 \div 2,3$ мкм;

- резонансная частота: $115 \div 190$ кГц;

- силовая константа: $2,5 \div 10 \mathrm{H} / \mathrm{M}$.

Зонды имеют алмазоподобное покрытие (DLC) кончиков. Отражающая сторона покрыта золотом. Характерный радиус кончика составляет $\leq 5$ нм. Данные характерные особенности обеспечивают прочность зонда и повышенную разрешающую способность сканирования.

Также, в измерительных исследованиях использовался сканер с рабочими диапазонами в трех координатах 9x9x2 мкм³. Для процедуры сканирования были установлены следующие параметры:

- резонансная частота колебания кантилевера: 193,3 КГц;

- смещение от пика резонанса 0,1 кГц;

- пиковая амплитуда свободных (зонд удален от объекта) колебаний: 2 В;

- поддерживаемая обратной связью амплитуда колебаний зонда при сканировании поверхности $-70 \%$ от амплитуды свободных колебаний;

- интегральная чувствительность (I Gain) 50 \%;

- скорость сканирования: 1 линия/с;

- разрешение сканирования по X и Y: 512 точек. Перед началом измерения сканер был откалиброван с помощью тестовых образцов TGZ1 и TGZ2 (высоты ступенек 20,3 \pm 1,5 нм и $102,3 \pm 2$ нм соответственно, шаг ступенек для обоих мер 3,00 $\pm 0,01$ мкм) 
Обработка и анализ изображений производились с помощью программы инструмента визуализации и анализа данных C3M Gwyddion 2.55 с лицензией Open Source.

Исходное изображение подвергалось обработке, исключающей дефекты сканирования, которые обусловлены физическими недостатками пьезоприводов сканнера. Характерными дефектами изображений поверхности, формируемых сканерами подобного типа, являются, например, отклонение от фактической плоскостности поверхности измеряемого образца или частички грязи вплоть до субмикронного размера, которые отрываясь, нарушают стабильность контакта зонд-образец и проявляются на изображении в виде амплитудных всплесков.

Итак, для анализа геометрических параметров полученных наносфер исходное изображение подверглось следующей обработке:

- выравнивание данных вычитанием средней плоскости;

- исправление нуля;
- исключение полиномиального фона (горизонтальная и вертикальная степени полинома - 11).

Также были выбраны предельные значения для максимального снижения отклонения от плоскостности среднего уровня поверхности.

Установлено, что среднее значение высоты для исследуемых образцов составляет 54 нм, СКО - 16,7 нм. Результирующее изображение синтезированных наносфер и предварительно полученное характерное 2D-изображение участка поверхности подложки, на которой получали пленку, содержащую синтезированные наносферы, представлены на рисунке 2. Трехмерная реконструкция участка поверхности исследуемой пленки в сравнении с поверхностью подложки представлены на рисунке 3. Основными геометрическими объектами 2D-изображения являются окружности разного размера и с некоторой деформацией формы. Деформирование формы наиболее явно, в случае, когда эти объекты контактируют друг с другом. Если посмотреть на профили
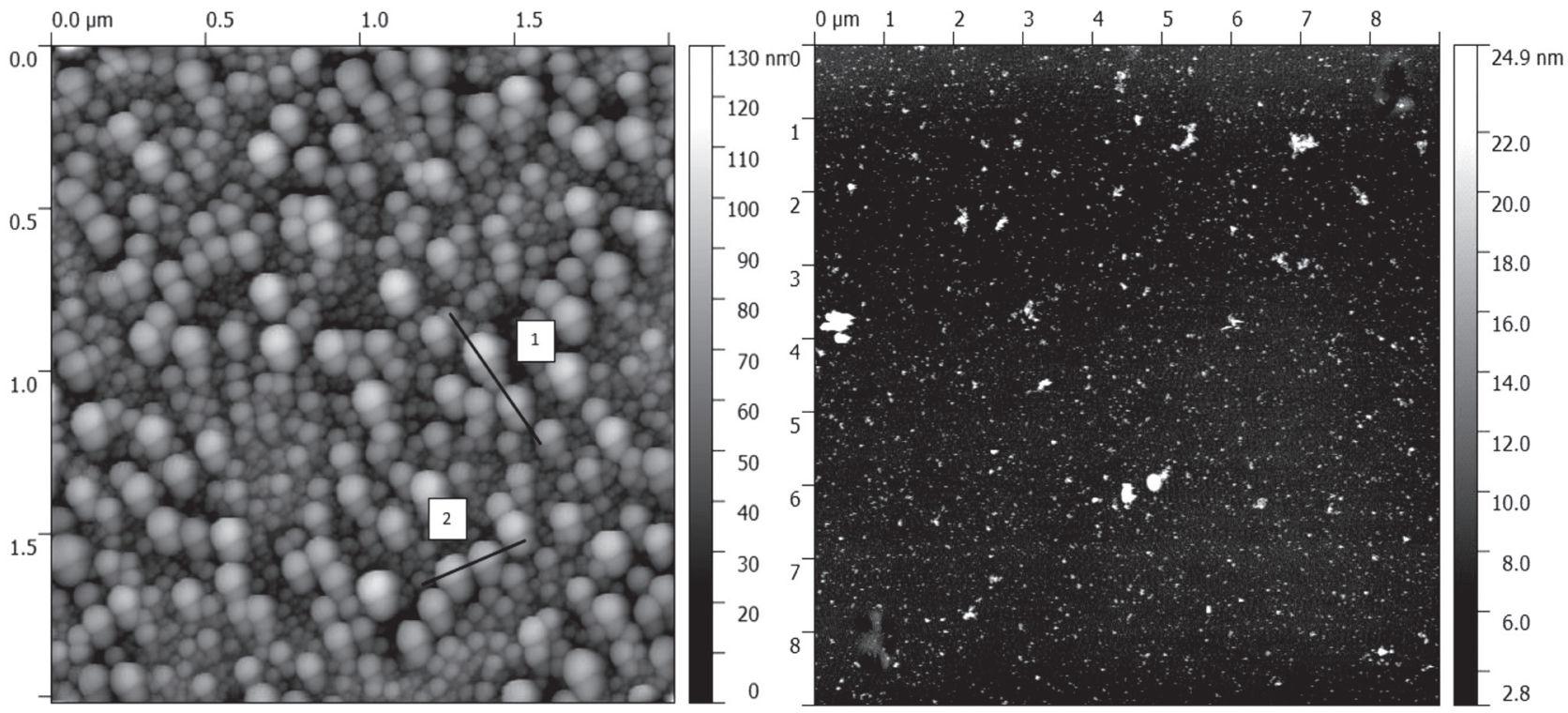

Рис. 2. Изображение участка поверхности пленки, полученной из раствора синтезированных наносфер (слева), и поверхность подложки (справа)
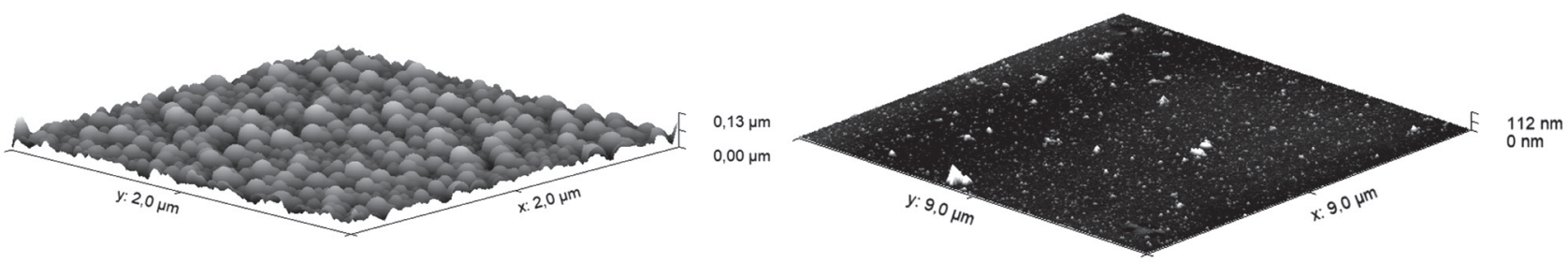

Рис. 3. Трехмерная реконструкция участка поверхности исследуемого образца (слева) и поверхности подложки (справа) 
поверхности, представленные на рисунке 4, извлеченные по линиям 1 и 2 (обозначены на рисунке 2), то видно, что геометрия линий, огибающих поверхность анализируемых объектов, имеют шарообразную форму.
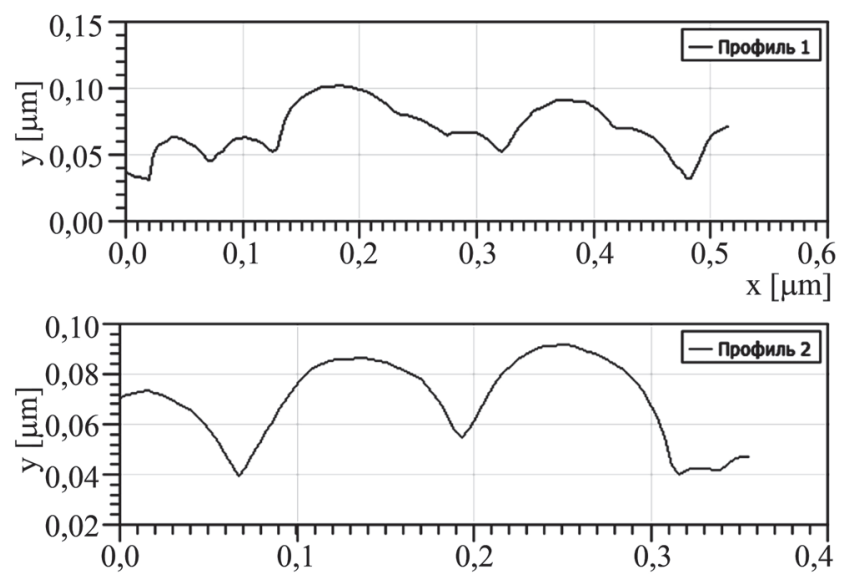

Рис. 4. Профили участков исследуемой поверхности

Оценка диаметра D производилась по 10 произвольным объектам различной яркости и с формами близкими к окружности. Таким образом, средний размер объектов составил 57,6 $\pm 10,9$ нм. При этом среднее значение высоты подложки составило 7,5 нм, СКО - 3 нм.

Таким образом, полученные данные хорошо коррелируют с результатами, полученными с помощью метода лазерной дифракции.

\section{Исследование флуоресценции полученных частиц}

Флуоресценцию полученных полистирольных наносфер с родамином $\mathrm{G}$ исследовали с помощью спектрофлуориметра RF-5301PC (Shimadzu, Япония). Для проведения измерения промытые сферы были диспергированы в воде в соотношении 1:1500 соответственно. Были заданы следующие параметры сканирования: ширина щели 5 нм, возбуждение флуоресценции при длине волны -470 нм. На рисунке 5 представлен спектр флуоресценции синтезированных наносфер, наполненных родамином $\mathrm{G}$.

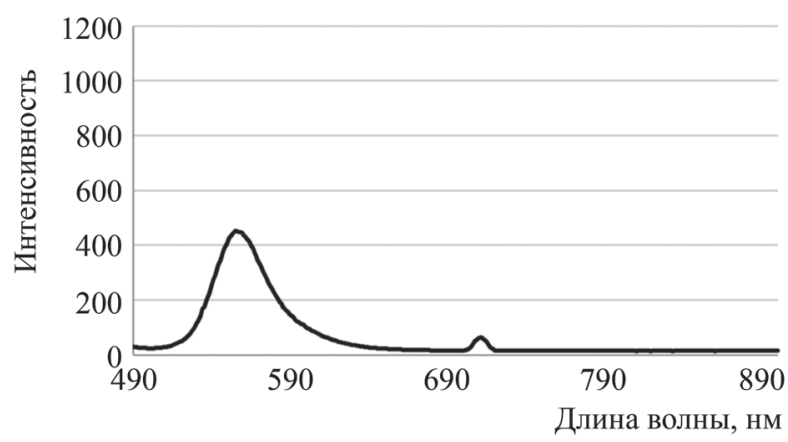

Рис. 5. Спектр флуоресценции синтезированных полистирольных наносфер с родамином $\mathrm{G}$

Пик флуоресценции для родамина $\mathrm{G}$ достигается при длине волны 555 нм, что соответствует флуоресценции наносфер с родамином.

Также стоит отметить, что полистирольные частицы плохо смачиваются водой, это делает их пригодными для использования при работе с водными растворами без риска вымывания красителя из пор полимера.

Таким образом, в результате работы были синтезированы полистирольные наносферы со средним размером 50 нм и узким распределением частиц по размерам, что подтверждается методами лазерной дифракции и атомно-силовой микроскопии.

Наличие флуоресценции синтезированных наносфер на длине волны 555 нм, соответствующей флуоресценции родамина $\mathrm{G}$, свидетельствует об успешной модификации синтезированных сфер.

Микросферы, наполненные флуоресцентными молекулами или частицами, могут использоваться для иммунохимического анализа, исследований механики жидкости, новых лекарств, флуоресцентной микроскопии, фагоцитоза и др.

\section{Литература}

1. Sahil K. International Journal of Research in Pharmacy and Chemistry. 2011. P. 1184-1198. 